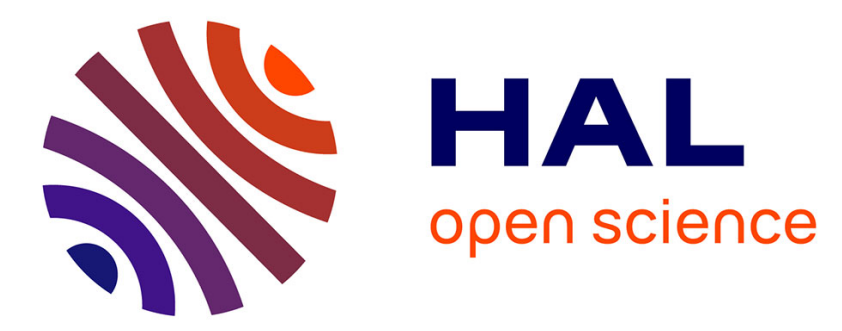

\title{
Autogenous modulation of the Bacillus subtilis sacB-levB-yveA levansucrase operon by levB transcript.
}

Jean-Pierre Daguer, Thomas Geissmann, Marie-Françoise Petit-Glatron, Régis

Chambert

\section{- To cite this version:}

Jean-Pierre Daguer, Thomas Geissmann, Marie-Françoise Petit-Glatron, Régis Chambert. Autogenous modulation of the Bacillus subtilis sacB-levB-yveA levansucrase operon by levB transcript.. Microbiology, 2004, 150, pp.3669-3679. 10.1099/mic0.27366-0 . hal-00009072v2

HAL Id: hal-00009072

https://hal.science/hal-00009072v2

Submitted on 8 Nov 2005

HAL is a multi-disciplinary open access archive for the deposit and dissemination of scientific research documents, whether they are published or not. The documents may come from teaching and research institutions in France or abroad, or from public or private research centers.
L'archive ouverte pluridisciplinaire HAL, est destinée au dépôt et à la diffusion de documents scientifiques de niveau recherche, publiés ou non, émanant des établissements d'enseignement et de recherche français ou étrangers, des laboratoires publics ou privés. 


\title{
Bacillus subtilis: characterisation and role of autogenous modulation of
}

\author{
sacB-levB-yveA levansucrase operon by levB transcript
}

\author{
Jean-Pierre Daguer, Thomas Geissmann, Marie-Françoise Petit-Glatron and Régis Chambert* \\ Institut Jacques Monod, Laboratoire Génétique et Membranes, CNRS/ Universités Paris 6 et Paris 7 \\ Tour 43, 2 place Jussieu, 75251 Paris Cedex 05, France
}

* Corresponding author:

Régis Chambert, Tel: + 331442747 19. Fax: +33144275994.

e-mail: chambert@,ccr.jussieu.fr

\section{SUMMARY}

Silencing of levB, the second structural gene of the tricistronic levansucrase operon encoding the endolevanase LevB, decreases the level of levansucrase expression. Conversely, independent expression of levB greatly stimulates operon expression. This autogenous effect is mediated by the $l e v B$ transcript, which carries an internal sequence (5'-AAAGCAGGCAA-3') involved in the enhancing effect. In vitro, the levB transcript displays an affinity to the N-terminal fragment of SacY, the regulatory protein that prevents transcription termination of levansucrase operon, $\left(K_{D}=0.2 \mu M\right)$. Simulation of the dynamics of operon expression showed that this positive feedback loop increases the capacity of Bacillus subtilis to produce the three proteins encoded by the operon when bacteria are grown in the presence of high concentrations of sucrose. Under such conditions, extracellular levan synthesized by the fructosyl polymerase activity of levansucrase can be degraded mainly into levanbiose by the action of LevB. Levanbiose is neither taken up nor metabolized by the bacteria. This work modifies the present view of the status of levansucrase in $B$. subtilis physiology.

\section{INTRODUCTION}

The levansucrase tricistronic operon of Bacillus subtilis consists of an upstream cis-acting control region, the $s a c R$ locus (Aymerich et al., 1986), and three genes $s a c B$, levB and yveA, the transcription of which is simultaneously induced by sucrose (Pereira et al., 2001b).

Levansucrase, encoded by $s a c B$, is a secreted enzyme whose in vivo and in vitro catalytic activities are well characterized (Dedonder, 1966; Chambert et al., 1974). The enzyme acts mainly as a sucrose hydrolase when the concentration of sucrose is low $(<10 \mathrm{mM})$. At higher concentrations of sucrose, levansucrase catalyses the formation of high molecular mass fructan of the levan type by the addition of fructosyl residues from sucrose. The enzyme is able to hydrolyse levan into fructose, but its exolevanase activity is arrested at the $2 \rightarrow 1$ branch points of the polymer (Rapoport \& Dedonder, 1963). Only $30 \%$ of available fructose is released by the prolonged action of the enzyme on the polymer.

The protein encoded by $\operatorname{lev} B$ is a peripheric membrane protein remaining anchored to the cytoplasmic membrane and displays an endolevanase activity, which has been preliminarily characterized (Pereira et al., 2001b). YveA, the third protein, might function as a permease, as predicted by its similarity to proteins of known function (Kunst et al., 1997). Its numerous predicted transmembrane segments suggest that YveA is a membrane intrinsic protein.

Northern blotting analyses with specific probes showed that, under exponential phase of growth and in the presence of $50 \mathrm{mM}$ sucrose, the yield of the full length tricistronic transcript $s a c B-l e v B-y v e A$ was lower than that of the bicistronic $s a c B-\operatorname{lev} B$, whose yield is itself about $10 \%$ of the monocistronic $s a c B$ mRNA (Pereira et al., $2001 \mathrm{~b})$. This results from partial arrests of the RNA polymerase at the internal terminator structures located between $s a c B$ and $l e v B$, and $l e v B$ and yve $A$. Considerable efforts have been made in the last three decades (Lepesant et al., 1972; Steinmetz et al., 1985; Tortosa \& Le Coq, 1995, 1997; Idelson \& Amster-Choder, 1998; Declerck et $a l ., 2002)$ to identify the mechanism underlying $s a c B$ expression and to situate within the carbohydrate catabolism network of $B$. subtilis the role and regulation of this gene involved in the metabolism of sucrose. All the molecular genetic investigations were carried out on the 
assumption that the monocistronic $\operatorname{sac} B$ locus encodes only levansucrase. Within this context, it was difficult to find a satisfying explanation concerning the physiological function of this enzyme, because $B$. subtilis possesses a higher efficient pathway for sucrose metabolism constituted of a PTS dependent permease specific for sucrose and an intracellular sucrase (Lepesant et al., 1972). Therefore, we considered stimulating to reopen the debate from the finding that LevB is a part of a functional unit composed of the three proteins encoded by the operon.

We anticipated that the expression of the two additional proteins of the operon might play a role in the function and regulation of the operon expression by means of the transport or metabolism of sucrose or its derivatives.

In order to study this hypothesis, we first carefully characterized the catalytic activity of LevB and we investigated the contribution made by the expression of lev $B$ and yveA to the regulation of operon expression. The silencing of these two operon distal genes led to a decrease in $s a c B$ expression by a factor of two. Independent expression of yve $A$ had no effect on $s a c B$ expression. In contrast, overexpression of $l e v B$ greatly increased the level of SacB synthesis. Surprisingly, this enhancing effect was not related to the catalytic activity of $\operatorname{lev} B$. We found however that the $\operatorname{lev} B$ transcript carries a short internal sequence identical to a motif of eleven nucleotides present in the leader region of the operon. We therefore explored the possibility that an interaction existed between the $\operatorname{lev} B$ transcript and the components of the transcription antitermination system that controls expression of the operon.

\section{METHODS}

Bacterial strains and media. The strains and plasmids used are listed in Table 1. All the strains constructed were obtained by transformation with replicative or integrative plasmids of strain GM96100, a derivative of the degU32(Hy) Bacillus subtilis mutant (Leloup et al.,1997). Bacteria were grown at $37^{\circ} \mathrm{C}$ in minimal medium (Chambert \& Petit-Glatron, 1984) supplemented with $1 \%$ $(\mathrm{w} / \mathrm{v})$ glucose. One optical density (OD) unit at $600 \mathrm{~nm}$ of cell suspension $\quad\left(\approx 10^{8}\right.$ bacteria $)$ corresponds to approximately $100 \mu \mathrm{g} \mathrm{ml}^{-1}$ protein (Chambert \& PetitGlatron, 1984). Escherichia coli XL1-Blue strain and its transformants were grown in TerB rich medium (Sambrook et al., 1989) containing $150 \mathrm{mg}$ ampicillin $\mathrm{ml}^{-1}$.

Plasmid and strain constructions. All the DNA fragments were amplified by PCR with primers including restriction sites, as indicated in Table 2, from the chromosomal DNA of strain QB112 isolated as described by Leloup et al. (1997). The amplified blunt-ended fragments were inserted into the $\mathrm{pCR}(+)$ vector at the SrfI site, after appropriate treatment, according to the supplier's recommendations (Stratagene). The resulting plasmids were used to transform E. coli XL1-Blue.
Plasmids purified from E.coli transformants exhibiting fragments of the expected size after digestion by various endonucleases were selected and the complete sequence of the fragments inserted was controlled using appropriate primers.

Construction of plasmid pGMK80. This integrative plasmid was constructed in order to introduce, by double crossing over, DNA fragments into the $\operatorname{sacR}-\operatorname{sacB}$ chromosomal site and was obtained as follows: pGMK50 (Petit-Glatron \& Chambert, 1992) was digested by EcoRV and re-ligated. Plasmid pGMKD50, from which the EcoRV fragment had been deleted, was selected. A $1 \mathrm{~kb}$ $\mathrm{H} 1$ fragment corresponding to the chromosomal sequence upstream from $s a c R-s a c B$ was amplified by PCR from genomic DNA of strain QB112 using oligonucleotides $\mathrm{H} 1-\mathrm{fw}$ and $\mathrm{H} 1-\mathrm{rev}$ as primers containing the restriction sites $A v a \mathrm{I}$ and BamHI, respectively, and inserted into $\mathrm{pCR}(+)$ vector as described above, resulting in plasmid pGMC20. H1 fragment was purified from this plasmid after digestion by $A v a \mathrm{I}$ and $B a m \mathrm{HI}$ and ligated into pGMKD50, digested with the same enzymes. An appropriate plasmid was selected and named pGMK 80 .

Construction of plasmid derivatives of pWH1520. The structural genes $\operatorname{lev} B$ or yveA were amplified by PCR using oligonucleotides levB-fw and levB-rev1 or yveA-fw and yveA-rev (Table 2) containing the restriction sites SpeI and KpnI, respectively. The amplification products were cloned into $\mathrm{pCR}(+)$ vector. The resulting plasmids pGMC21 and pGMC22 were digested with SpeI and KpnI. The DNA fragments $\operatorname{lev} B(1.6 \mathrm{~kb})$ or yve $A(1.6 \mathrm{~kb})$ were ligated into pWH1520 (Rygus et al., 1991) digested with the same enzymes giving plasmids pWHlevB or pWHyveA.

Construction of plasmid pWHlevBmut. Plasmid pGMC21 containing the $\operatorname{lev} B$ gene sequence was used as a template to amplify two PCR DNA fragments using oligonucleotides levBmut and KS and levB-rev2 and T3 (Table 2). The two PCR products of approximately 1650 $\mathrm{bp}$ and $50 \mathrm{bp}$ were then mixed and reamplified with oligonucleotides $\mathrm{KS}$ and $\mathrm{T} 3$. The resulting PCR product was cloned into $\mathrm{pCR}(+)$, giving $\mathrm{pGMC} 23$ which was sequenced using appropriate oligonucleotides. The mutated levB gene was SpeI-KpnI digested and cloned into pWH1520. The plasmid was named pWHlevBmut.

Construction of strain GM2101: The levansucrase structural gene $s a c B$ was amplified using oligonucleotides LS-fw and LS-rev containing the restriction sites AatII and XhoI (Table 2) and cloned into the $\mathrm{pCR}(+)$ vector as described above. The $1.4 \mathrm{~kb}$ DNA fragment obtained by AatII and XhoI digestion was purified and ligated into plasmid pGMC9, digested with the same enzymes, which contains the sacR locus cloned as a BamHI/AatII fragment (Leloup et al., 1999). The plasmid obtained, pGMC24, was digested with BamHI and EcoRV and the corresponding fragment was inserted into pGMK80 digested with the same enzymes. The resulting plasmid was used to transform E. coli XL1-Blue. The correct sequence of the inserted fragment was verified from purified plasmids and levansucrase activity was assayed in 
the cell extracts of the transformants. An appropriate plasmid (pGMK81) was chosen to transform strain GM96100.

Transformants were selected on LB plates for both their resistance to kanamycin $\left(10 \mathrm{mg} \mathrm{ml}^{-1}\right)$ and their sensitivity to spectinomycin $\left(100 \mathrm{mg} \mathrm{ml}^{-1}\right)$ and chloramphenicol $\left(3 \mathrm{mg} \mathrm{ml}^{-1}\right)$. One of the transformants exhibiting sucrose inducible expression of levansucrase was chosen and named GM2101.

Construction of strain GM2102. The endolevanase structural gene $\operatorname{lev} B$ sequence was amplified by PCR as described by Pereira et al. (2001b). The amplification product was cloned in $\mathrm{pCR}(+)$ vector.The resulting plasmid was digested with AatII and EcoRV. The $1.6 \mathrm{~Kb}$ fragment containing the $\operatorname{lev} B$ gene was ligated into pGMC9. The transcriptional fusion $\operatorname{sacR}$-levB was then purified by BamHI EcoRV digestion and ligated into pGMK80 resulting in plasmid pGMK82 which was used to transform GM96100. Transformants were selected on LB plates for both their resistance to kanamycin $\left(10 \mathrm{mg} \mathrm{ml}^{-1}\right)$ and their sensitivity to spectinomycin $\left(100 \mathrm{mg} \mathrm{ml}^{-1}\right)$ and chloramphenicol $\left(3 \mathrm{mg} \mathrm{ml}^{-1}\right)$. One of the transformants exhibiting sucrose inducible expression of LevB was chosen and named GM2102.

Construction of strains GM2201,GM2202, GM2203, GM2204. These strains were obtained by transformation of strain GM2101 with the replicative plasmid pWH1520 (GM2201) and its derivatives pWHlevB (GM2202), pWHyveA (GM2203) and pWHlevBmut (GM2204).

Levansucrase assay. Levansucrase activity was estimated by measuring the initial rate of the fructosyl exchange reaction (Chambert et al., 1974). A reaction mixture (20 $\mu 1)$ containing $0.2 \mathrm{M}$ uniformly labeled $\left[{ }^{14} \mathrm{C}\right]$ glucose and $0.1 \mathrm{M}$ sucrose in $0.05 \mathrm{M}$ phosphate buffer $\mathrm{pH} 6$ was incubated at $30{ }^{\circ} \mathrm{C}$ for $10 \mathrm{~min}$. The reaction was initiated by the addition of $5 \mu 1$ of culture supernatant. Aliquots of 8 $\mu 1$ were removed at intervals and ${ }^{14} \mathrm{C}$ labeled sugars were quantitatively analyzed by paper chromatography. One unit of enzyme activity (EU) defined as the amount of enzyme exchanging $1 \mu$ mole glucose $\mathrm{min}^{-1}$ corresponds to $2 \mathrm{mg}$ of levansucrase..

LevB assay. Uniformly labelled $\left[{ }^{14} \mathrm{C}\right]$ levan was prepared by the action of immobilized levansucrase on $\left[{ }^{14} \mathrm{C}\right]$ sucrose and used as a substrate (Chambert \& Petit-Glatron, 1993). LevB was assayed on the membrane fraction obtained as previously described by Pereira et al. (2001b).

RNA techniques. Total RNA extraction, Northern blotting and mRNA half-life determinations were done as described by Pereira et al. (2001a, 2001b). We confirmed transcription of $\operatorname{lev} B$ or yveA in strains GM2202 or GM2203 grown in minimal medium upon xylose induction by Northern blotting using, as probes, the lev $B$ and yve $A$ genes purified from plasmid pGMC21 and pGMC22, respectively, by SpeI/KpnI digestion. Probes were radiolabelled with $\left[\mathrm{a}^{33} \mathrm{P}\right]$ ATP by random priming using Amersham DNA Megaprime Labelling System.
In vitro transcription. The DNA template (pWHlevB or $\mathrm{pWHlevBmut)}$ for in vitro transcription was generated by PCR with forward primer levB-T7 containing the T7 promoter sequence and reverse primer levB-332rev. RNA was then produced by transcription in vitro with $\mathrm{T} 7$ polymerase (T7 Megashortscript kit, Ambion). Transcripts were de-phosphorylated with alkaline phosphatase and radioactively labelled at the 5 ' end with $\left[\mathrm{g}_{-}{ }^{32} \mathrm{P}\right] \mathrm{ATP}$ and $\mathrm{T} 4$ polynucleotide kinase (Kinasemax labelling kit, Ambion). The radioactively labelled RNA was purified on a denaturing $8 \%(\mathrm{w} / \mathrm{v})$ polyacrylamide $/ 8 \mathrm{M}$ urea gel and eluted in $0.5 \mathrm{M}$ ammonium acetate, $1 \mathrm{mM}$ EDTA and $0.1 \%(\mathrm{w} / \mathrm{v})$ SDS. The transcripts were collected by ethanol precipitation and suspended in $10 \mathrm{mM}$ Tris/- $\mathrm{HCl}, \mathrm{pH} 8.5$.

\section{RESULTS}

Catalytic activity of LevB. In order to increase LevB synthesis, which production is very low in the context of the levansucrase operon (Pereira et al., 2001b), we constructed strain GM2102 in which $\operatorname{lev} B$ expression was under the control of the $s a c R$ leader region of the operon as described in Methods. Under these conditions, LevB was overproduced which made it possible to analyse, in vitro, the catalytic specificity of this enzyme in its membrane associated form.

We first identified the products released by LevB acting on levan. Results showed (Fig. 1a) that the main products, identified by chromatographic migration and subsequent analysis of acid hydrolysed products, were fructose, levanbiose (difructose) and levantriose (trifructoside). After incubation for $6 \mathrm{~h}$ (Fig. 1b), these compounds represented 32, 55 and $7.4 \%$ of available fructose, respectively. After a longer incubation time, levanbiose reached $62 \%$ and remained stable. In addition, we observed that LevB is devoid of any catalytic activity on sucrose, the only known inducer of the levansucrase operon. LevB is unable to use this sugar either as a fructosyl donor or as a fructosyl acceptor (results not shown).

Silencing of both $l e v B$ and yve $A$ gene leads to a decrease in $\operatorname{sac} B$ expression. Silencing of the $\operatorname{lev} B$ and yve $A$ genes was carried out by disrupting the operon $s a c B-\operatorname{lev} B-y v e A$. For this purpose a transcriptional fusion $s a c R-s a c B-\mathrm{Km}^{\mathrm{R}}$ was inserted by double crossing-over into the chromosome of strain GM96100 deleted of the $s a c R-s a c B$ region (Leloup et al., 1997) (Fig. 2a). In the resulting strain, GM2101, introduction of the $\mathrm{Km}^{\mathrm{R}}$ cassette prevented the expression of $\operatorname{lev} B$ and $y v e A$, the last two genes of the operon. This silencing did not affect the growth rate of the cells. Endolevanase LevB activity was not detected in membrane fractions and the differential rate of levansucrase synthesis induced by sucrose was approximately $3 \%$ of total protein compared to strain QB112 in which levansucrase production represented $6.5 \%$ of total protein after full sucrose induction (Fig. 2b). This result suggests that the products of levB or yveA 
expression participate in an auto-activation mechanism of levansucrase operon expression.

Independent expression of levB greatly increases levansucrase production whereas expression of yveA has no effect. In order to determine which of the two candidate genes affected levansucrase production, we cloned each gene under the control of an inducible promoter $x y l A$ in plasmid pWH1520 (Rygus et al., 1991). Strain GM2101 was transformed as indicated in Methods with plasmids pWH1520, pWHlevB and pWHyveA and the corresponding tetracycline resistant strains GM2201, GM2202 and GM2203 were grown in minimal medium. Transcription of $l e v B$ or yve $A$ upon xylose induction in strain GM2202 or GM2203 was confirmed by Northern blotting (not shown). Levansucrase synthesis subsequent to sucrose addition was measured in the presence of various concentrations of xylose (Fig. 3). When xylose was used within a range of $0-2 \%(\mathrm{w} / \mathrm{v})$ xylose, a four fold increase in levansucrase synthesis was obtained in strain GM2202. Production of levansucrase corresponded to $13 \%$ of total cellular proteins under optimum conditions of induction. Pulse-chase experiments carried out as described by Chambert \& Petit-Glatron (1988) indicated that the kinetics of levansucrase was not modified by LevB overproduction. A similar experiment was carried out with yveA. The results obtained indicate that independent expression of this gene has no effect on the production of levansucrase. Given the results, we concluded that SacB synthesis depends on $\operatorname{lev} B$ gene expression. We therefore question whether the enhancing effect of $l e v B$ expression is exerted at the transcriptional or translational level.

Expression of levB increases the yield of $s a c B$ transcription but not mRNA stability or translation efficiency of $\boldsymbol{s a c B}$. Northern blotting analysis of $s a c B$ transcripts was carried out with the $s a c R$ probe (Pereira et al., 2001b) in strains GM2201 and GM2202. The results indicated a three fold increase in the steady state level of $s a c B$ transcripts in strain GM2202 which overexpressed lev $B$ compared to strain GM2201 (Fig. 4a). We analysed the kinetics of $s a c B$ mRNA decay in the two strains by Northern blotting after inhibition of transcription initiation by rifampicin. Quantification of the labelled bands on the Northern blot gave similar values for the two strains, $120 \mathrm{~s}$ \pm 30 (GM2201) and $126 \mathrm{~s} \pm 25$ (GM2202) (Fig. 4b). Quantification of the increase in the amount of levansucrase synthesized was also performed after addition of rifampicin (Fig. 4c) to determine the functional mRNA stability. The half-life values deduced from the curves were $105 \mathrm{~s} \pm 20$ for strain GM2201 and $115 \mathrm{~s} \pm 18$ for strain GM2202. The two methods resulted in the estimation that the half-lives of $s a c B$ mRNA were similar in the two strains. Moreover, the ratio of the total amount of levansucrase synthesized in each strain (Fig. 4c), after inhibition of the transcription initiation was the same as the ratio of the steady state $s a c B$ mRNA quantified from Northern blotting analyses (Fig. 4a). It can be concluded that the increase in levansucrase production due to $\operatorname{lev} B$ expression is exerted at the transcriptional level.

The enhancing effect of levB expression on $s a c B$ transcription is not related to the catalytic activity of LevB. Control of $s a c B$ gene expression has been thoroughly investigated during the last two decades (Aymerich et al., 1986; Crutz et al., 1990). All the results obtained support the conclusion that sucrose induction of the $s a c B$ gene occurs via an antitermination mechanism involving the $s a c X / Y$ regulatory operon of $B$. subtilis. We therefore explored the hypothesis that the enhancing effect of the independent $l e v B$ expression is mediated by the products of the catalytic activity of LevB, which might be a better inducer than sucrose.

We have shown above that LevB acts on levan only and has no catalytic action on sucrose, the inducer of $s a c B$ expression. Previous work showed that levansucrase is able to catalyse levan synthesis only when the sucrose concentration is higher than $10 \mathrm{mM}$ (Chambert \& GonzyTreboul, 1976). It was therefore interesting to test whether the transcription enhancing effect of $\operatorname{lev} B$ expression could be observed in the absence of levan synthesis. The sucrose induction profiles of levansucrase production by strains GM2201 and GM2202 were compared with that of strain QB112 (Fig. 5). First we observed that the presence of sucrose was required to induce levansucrase expression in the three strains. However, the response curves of $\mathrm{SacB}$ production to the inducer are quite different. One of the main features concerned inducer concentrations required to reach full induction. The concentration was lower than 20 mM for strain GM2201 and GM2202, whereas it was equal or higher than $50 \mathrm{mM}$ for the reference strain QB112. This point will be clarified by the simulation approach proposed below. Secondly, the enhancing effect of lev $B$ expression (strain GM2202) occurs at $0-10 \mathrm{mM}$ sucrose, concentrations at which levan, the substrate of LevB, is not synthesized. This result suggested that the enhancing effect of lev $B$ expression is not dependent on the catalytic activity of LevB. To confirm this, we added to the cell suspension a mixture of levanbiose plus fructose obtained in vitro by digestion of levan by LevB (see legend to Fig. 1). No effect on levansucrase production was observed (results not shown).

It can be concluded that there is no relation between the enzyme activity of LevB and the enhancing effect of $l e v B$ expression on levansucrase production. We therefore propose the unconventional hypothesis that the $\operatorname{lev} B$ transcript can act as a transcriptional activator.

The $l e v B$ transcript carries a sequence motif involved in the enhancing effect. Sequence comparison of the noncoding sacR operon leader region and the three genes of the levansucrase operon showed that the $\operatorname{lev} B$ gene shares an identical sequence of 11 nucleotides with $\operatorname{sacR}$ (Fig. 6). This motif is included in the 29 nucleotides of the ribonucleic anti-terminator (RAT) sequence folded into a stem loop structure essential for an efficient interaction with SacY, the anti-terminator protein (Declerck et al., 
2002). To question whether this motif plays a role in the enhancing effect of lev $B$ expression, we substituted by sitedirected mutagenesis codons synonymous to those included in the motif. The codons AAA, GCA, GGC were replaced by AAG, GCG, GGG which modify the sequence without modifying the amino acid sequence of the protein. Strain GM2204 carrying the mutated $l e v B$ gene under the control of xylA promoter was grown in the absence or in the presence of $1 \%$ xylose. Levansucrase production subsequent to sucrose addition is similar under both conditions. This result indicated that the mutations introduced in the sequence motif of $\operatorname{lev} B$, identical to the RAT, impair its capacity to improve levansucrase production when compared with strain GM2202.

In vitro the transcript levB displays an affinity to SacY, the antitermination protein of the operon. We tested the ability of the $\operatorname{lev} B$ transcript to bind SacY, the antitermination protein of the operon. We used similar experimental conditions to those used by Manival et al. (1997) to demonstrate specific binding of SacY (1-55) to the RAT sequence of the leader region.

A fragment of 144 nucleotides of levB mRNA containing the motif AAAGCAGGCAA was generated by in vitro transcription as described in Methods and subjected to gel mobility shift experiments. One major shift was detected when the $\operatorname{lev} B$ fragment was incubated with GST::SacY(155) fusion protein (Fig. 7a). The intensity of the shifted band was not affected by the presence of increasing amounts of 5S rRNA indicating that $\operatorname{SacY}(1-55)$ specifically binds the lev $B$ mRNA fragment (Fig. 7b). The affinity constant of $\operatorname{SacY}(1-55)$ to levB mRNA was evaluated from gel shifts repeated with various amounts of GST::SacY(1-55) fusion protein (Fig. 7c). The binding pattern was quantified and gave an estimate of $0.2 \mu \mathrm{M}$ for the dissociation constant. When the mutated levB mRNA fragment was used in the same experiment, the binding pattern was greatly modified (Fig. 7d) and in this case the affinity constant of $\mathrm{SacY}(1-55)$ to $\operatorname{lev} B$ mRNAwas estimated to $5 \mu \mathrm{M}$.

Modelling of the dynamics of the induction of levansucrase operon. The expression of the $s a c B$ gene has been shown to be regulated by transcription antitermination involving the binding of SacY to the transcript (Aymerich \& Steinmetz, 1992; Declerck et al., 2002). This mechanism is characterized by a constitutive transcription of the operon leader region. When sucrose (the inducer) is absent, the transcript of the leader region folds into a stable terminator which serves as a transcription pause signal. $\mathrm{SacY}$ prevents termination allowing readthrough transcription by stabilizing an antiterminator structure. The active state of SacY depends on the activity of SacX, a sucrose permease which is possibly involved in catalyzing the reversible phosphorylation of SacY (Idelson \& AmsterChoder, 1998). This mechanism is not contested by our finding that $s a c B$ is the proximal gene of a sucrose inducible tricistronic operon including $\operatorname{lev} B$ and yve $A$. However, the results presented above suggest an additional circuit of control. levB transcript exerts, via its interaction with $\mathrm{SacY}$, a positive feedback modulation of transcription of the levansucrase operon mainly under conditions of high inducer concentrations. Using quantitative modelling, we attempted to simulate the dynamics of the response of this system to various signal values.

We propose that functional SacY can exist under the free form $\mathrm{SacY}_{\mathrm{f}}$ or associated with $\operatorname{levB}$ transcript, $\mathrm{SacY}_{\mathrm{a}}$. This association could stabilize the active dimeric form of SacY (Manival et al., 1997). We postulate that the two forms display a similar affinity to the antiterminator site. However, the delay time for the subsequent destabilization of the terminator hairpin structure could be shorter in the presence of $\mathrm{SacY}_{\mathrm{a}}$. It results that the increase in the transcription frequency of the downstream coding region increases the yield of the transcript of each gene of the operon.

If $\mathrm{SacY}_{\mathrm{T}}$ is the total cellular concentration of functional $\mathrm{Sac} \mathrm{Y}$ at any inducer concentration, the following equations can be established:

$$
\begin{aligned}
& \left(\mathrm{SacY}_{\mathrm{T}}\right)=\left(\mathrm{SacY}_{\mathrm{f}}\right)+\left(\mathrm{SacY} \mathrm{Y}_{\mathrm{a}}\right) \\
& \frac{\left(\mathrm{SacY}_{\mathrm{f}}\right)}{\left(\mathrm{SacY}_{\mathrm{T}}\right)}=\frac{\mathrm{K}_{\mathrm{D}}}{\mathrm{K}_{\mathrm{D}}+[\text { levBtranscript }]} \\
& \frac{\left(\mathrm{SacY}_{\mathrm{a}}\right)}{\left(\mathrm{SacY}_{\mathrm{T}}\right)}=\frac{[\text { levBtranscript }]}{\mathrm{K}_{\mathrm{D}}+[\text { levBtranscript }]}
\end{aligned}
$$

where $\mathrm{K}_{\mathrm{D}}$ is the dissociation constant of the $\mathrm{SacY}_{\mathrm{a}}$ complex.

Since $\mathrm{SacB}$ production is well documented, we focused our attention on the dynamics of $s a c B$ transcript accumulation in cells, after the addition of sucrose. We can model this event by writing the phenomenological dynamical equation $\frac{\mathrm{d}[\operatorname{sacB} \text { transcript }]}{\mathrm{dt}}=\mathrm{f}\left(\mathrm{SacY}_{\mathrm{T}}, \operatorname{levB\text {transcript})}-\mathrm{k}_{\mathrm{d}}(\right.$ sacBtranscript $)$ The first term corresponds to a positive effect of functional $\mathrm{SacY}$ and $\operatorname{lev} B$ transcript on the rate of $s a c B$ transcript synthesis. The second term corresponds to the decay rate of $\mathrm{sacB}$ transcripts. The function $\mathrm{f}$ cannot be obtained from experiments since it is difficult to accurately quantitate the cellular level of functional $\mathrm{SacY}_{\mathrm{T}}$ (Idelson \& AmsterChoder, 1998). Therefore, we propose to express the rate of $s a c B$ transcript synthesis with respect to the external inducer concentration using data obtained with the mutants constructed in this work.

We observed that the response curves of SacB production to the inducer for the strains GM2201 and GM2202 were hyperbolic (Fig. 8). These findings suggest that the cellular steady state level of $s a c B$ transcript depends on sucrose (I) according to the following equation:

$[\operatorname{sacB} \text { transcript }]_{\mathrm{st}}=[\operatorname{sacBtranscript}]_{\mathrm{st}}^{\mathrm{M}} \frac{\mathrm{I}}{\mathrm{K}_{\mathrm{I}}+\mathrm{I}}$

From the induction pattern of each strain, a similar value for the inducer concentration leading to 
$[s a c B \text { transcript }]_{\mathrm{st}}=\frac{1}{2}[\operatorname{sacB\text {transcript}}]_{\mathrm{st}}^{\mathrm{M}} \quad$ was

evaluated, $\mathrm{K}_{\mathrm{I}}=8 \mathrm{mM}$. Since strain GM2201 does not synthesize $\operatorname{lev} B$ transcript, it results that, in this strain, functional $\mathrm{SacY}$ is active in its $\mathrm{SacY}_{\mathrm{f}}$ form only. Conversely, under conditions of overproduction of $\operatorname{lev} B$ transcript it can be assumed that functional $\mathrm{SacY}$ is active in its $\mathrm{SacY}_{\mathrm{a}}$ form in GM2202.

We previously correlated the rate of SacB production in $B$. subtilis with the steady state yield of $s a c B$ mRNA (PetitGlatron \& Chambert, 1981). Combination of this data with the decay rate of the entity, $\mathrm{k}_{\mathrm{d}}=0.35 \mathrm{~min}^{-1}$ enabled us to evaluate the rate of $s a c B$ mRNA synthesis in the cells of each strain at any inducer concentration. The maximum rates were estimated to be $0.14 \mu \mathrm{M} \mathrm{min}^{-1}$ and $0.6 \mu \mathrm{M} \mathrm{min}^{-1}$ for strains GM2201 and GM2202, respectively.

Therefore, the dynamics of $s a c B$ mRNA synthesis subsequent to sucrose addition in such bacteria suspension are represented by the following equations

Strain GM2201

$$
\frac{\mathrm{d}(\operatorname{sac} B \mathrm{mRNA})}{\mathrm{dt}}=0.14 \frac{\mathrm{I}}{\mathrm{K}_{\mathrm{I}}+\mathrm{I}}-\mathrm{k}_{\mathrm{d}}(\operatorname{sac} B \mathrm{mRNA})
$$

StrainGM2202

$$
\frac{\mathrm{d}(\operatorname{sac} B \mathrm{mRNA})}{\mathrm{dt}}=0.6 \frac{\mathrm{I}}{\mathrm{K}_{\mathrm{I}}+\mathrm{I}}-\mathrm{k}_{\mathrm{d}}(\operatorname{sac} B \mathrm{mRNA})
$$

These equations were established by postulating that the rate of SacY transition from the inactive to the active state is an instantaneous process compared to the transcription process at any sucrose concentration.

The reference strain $\operatorname{deg} U_{32}(\mathrm{Hy})$ produces both the monocistronic $s a c B$ mRNA and the bicistronic $s a c B-\operatorname{lev} B$ mRNA (Pereira et al., 2001b). This latter molecule, which carries the transcriptional enhancing motif, is not produced to the same extent as that of the monocistronic $s a c B$ mRNA depending on the yield of the readthrough of the internal terminator structure located between $s a c B$ and levB. In addition, we have experimentally evaluated (results not shown) that the apparent rate constant of the decay reaction of the bicistronic mRNA is similar to that of the monocistronic mRNA. The transition from SacY to $\mathrm{SacY}_{\mathrm{a}}$ is modulated by the bicistronic mRNA according to [1]. Therefore if $\mathrm{x}$ stands for $\operatorname{sacB}$ mRNA, one can describe the dynamics of accumulation of this transcript in the reference strain by the rate equation:

$$
\frac{\mathrm{dx}}{\mathrm{dt}}=\frac{\mathrm{I}}{\mathrm{K}_{\mathrm{I}}+\mathrm{I}}\left[0.14 \frac{\mathrm{K}_{\mathrm{D}}}{\mathrm{K}_{\mathrm{D}}+\mathrm{c} . \mathrm{x}}+0.6 \cdot \frac{\mathrm{c} . \mathrm{x}}{\mathrm{K}_{\mathrm{D}}+\mathrm{c} . \mathrm{x}}\right]-\mathrm{k}_{\mathrm{d}} \mathrm{x}
$$

[3]

Where $c$ is the yield of the readthrough of the internal terminator structure.

We numerically solved the model equations (Fig. 8) to study the effects of the positive feedback loop on the temporal approach of $s a c B$ mRNA to its steady state value when bacteria are in the presence of various inducer concentrations. We first compared (Fig. 8a, b) the dynamics of a system without a feedback loop with those of a system displaying a loop. The value of $\mathrm{c}$ was 0.1 , similar to that experimentally evaluated by Pereira et al. (2001b). The results obtained show that the enhancing effect of $\operatorname{lev} B$ transcript leads to an increase in both the steady state level of $s a c B$ mRNA and the lag period needed to reach this concentration. The magnitude of such effects increases as the inducer concentration increases. These results are in good agreement with the experimental data shown in Fig. 5 and previous results (Petit-Glatron \& Chambert, 1981) that emphasized on the surprisingly large and unexplained induction lag period of levansucrase production in the presence of high sucrose concentrations. In addition, they suggest that the positive feedback loop plays a role mainly under these conditions. The simulation shows (Fig. 8c) that, if in vivo a modulation of readthrough of the internal terminator $s a c B-\operatorname{lev} B$ occurs, the feedback loop can greatly increase the capacity of $B$. subtilis to produce the proteins encoded by the operon.

\section{Differences in uptake and metabolization of fructose and levanbiose by $B$. subtilis}

When sucrose concentration is high, $B$. subtilis accumulates levan in its microenvironment via the polymerase activity of extracellular levansucrase. We show here that the fructosyl polymer is degraded into fructose and levanbiose by the catalytic activity of LevB located on the cell surface. The question arises whether both sugars are used as substrates in the carbon and energy metabolism of the microorganism. We therefore compared the fate of each ${ }^{14} \mathrm{C}$-labelled sugar after its addition to the growing cell suspension (Fig. 9). The results indicated that fructose was rapidly taken up and metabolized by the microorganism. In contrast, levanbiose was not transported within the cells and remained unmodified in the culture supernatant. The same surprising result was obtained when cells are grown in the presence of unlabelled fructose or sucrose that had been added in order to induce sugar transport systems. The same result was obtained whatever the B. subtilis strain tested: QB112, GM2201, GM2202 or GM2101. Moreover, we observed that levanbiose was not modified by SacB secreted by strains QB112 or GM2202. We can conclude that levanbiose is not used as a source of energy for $B$. subtilis under these conditions. We discuss below possible other roles which can be played by this small molecule.

\section{DISCUSSION}

The results presented in this work lead us to propose that the expression of levansucrase operon is modulated by a positive autogenous mechanism. This feedback loop requires transcripts of $\operatorname{lev} B$, the second gene of the operon. Autogenous regulation of operon expression is a mechanism common to a number of systems in both 
prokaryotes and eukaryotes. Until recently it was accepted (Goldberger, 1974; Serfling, 1989) that this mechanism involved proteins specified by a given structural gene of the operon acting as a regulatory macromolecule. But during the last decade it has been demonstrated that RNA molecules can also serve as transcriptional enhancers and repressors (Henkin \& Yanofsky, 2002). Riboswitches in the paradigms of genetic regulation in eukaryotes and prokaryotes are presently being subjected to intense investigation (Hesselberth \& Ellington, 2002; Le Hir et al., 2003; Nudler \& Mironov, 2004). The modern RNA world has recently undergone a resurgence of interest resulting from the discovery of the wide distribution and utility of miRNAs and siRNAS, the small RNA regulators of gene expression (Hesselberth \& Ellington, 2002 ).

The expression of an operon occurring via an antitermination mechanism requires antiterminator protein interaction with a very short RNA sequence. Therefore it is reasonable to expect that the cellular regulatory networks responsible for the integration of such operon behaviour into a set of metabolic reactions can use short sequence signals to mediate crucial regulatory decisions.

It was tempting to investigate whether the expression level of other operons involved in degradation of carbohydrates could be coordinated by the RNA sequence motif found in the lev $B$ transcript. We therefore tested the manner in which the 11 nucleotide sequence that plays the key role, was distributed on the $B$. subtilis chromosome. This sequence was found 13 times. Only four loci contain this sequence which lies within the leader region of $s a c B-\operatorname{lev} B$ $y v e A, \operatorname{sacP} A, b g l P H$ operons and $b g l S$ gene (Yang et al., 2002). Such a result could be fortuituous, resulting from the evolution of a common ancestor or could provide preliminary information concerning the organization of the complex regulatory network underlying the coordination of the synthesis of the different enzymes involved in carbohydrate metabolism in B. subtilis.

The finding that the feedback loop, mediated by the $\operatorname{lev} B$ transcript, modulates the levansucrase operon provides information concerning the physiological function of the operon. The loop increases $s a c B$ and $l e v B$ production when $B$. subtilis is grown in the presence of high sucrose concentrations. Under such conditions, the catalytic activities of extracellular levansucrase on the disaccharide release mainly glucose and levan into the external medium. The former metabolite is readily taken up and metabolized by the bacteria. Levan, which cannot be transported into the cells, can be degraded into levanbiose by LevB. Seemingly, B. subtilis is not equipped for the uptake of this sugar which as a consequence accumulates in the cell's environment.

What can its physiological role be if it is not used as a source of carbone or energy? We propose as a working hypothesis that it is a signalling molecule. B. subtilis is a soil bacterium, found in the rhizosphere of plants, which, in its natural environment, competes with other inhabitants of the same niche. The survival of this bacterium requires the production and diffusion of small molecules which might be sensed either by $B$. subtilis or by other soil microorganisms or by plants. It is now accepted that sugars (hexoses, disaccharides such as sucrose and trehalose) act as signalling molecules and play a central part in the control of plant metabolism, growth and development (Rollan et al., 2002; Smeekens, 2000). One could expect levanbiose to participate in interactions between plants and B. subtilis.

If this hypothesis turns out to be correct, it will change our vision of the status of the levansucrase in B. subtilis physiology. As previously noted, the contribution of levansucrase to sucrose metabolism is negligible in the wild type strain (Lepesant et al., 1976). The most efficient pathway for sucrose metabolism, which involves a PTS dependent permease specific for sucrose encoded by sacP and an intracellular sucrase encoded by $s a c A$, is fully induced in the presence of low sucrose concentrations (within the range of $1 \mathrm{mM}$ ) (Débarbouillé et al., 1991). Therefore, the crucial role of levansucrase operon induction by higher sucrose concentrations would be to synthesize levanbiose from sucrose via the synthesis of levan subsequently degraded. In this hypothesis levan is regarded as a source of levanbiose rather than a reserve of fructose. We are currently exploring the postulate that levanbiose is a signalling molecule.

Finally, modelling of operon expression showed that the destabilisation of the internal terminator structure located between $s a c B$ and $l e v B$ had a positive effect on the yield of operon transcription. If such a mechanism exists in the cell, it would allow B. subtilis to fit in with environmental conditions that require an overproduction of the enzymes encoded by the operon without any increase in the functional level of SacX and SacY.

\section{ACKNOWLEDGEMENTS}

We are grateful to members of the European Bacillus Secretion Group for valuable discussions during this work. We are also grateful to Antonia Kropfinger for revision of the English text. This work was supported by a grant from the European Commission (Biotech programme, QLK3CT-1999-00413).

\section{REFERENCES}

Aymerich, S. \& Steinmetz, M. (1992). Specificity determinants and structural features in the RNA target of the bacterial antiterminator proteins of the $\mathrm{BglG} / \mathrm{SacY}$ family. Proc Natl Acad Sci U S A 89, 10410-10414.

Aymerich, S., Gonzy-Tréboul, G. \& Steinmetz, M. (1986). 5'-noncoding region $s a c R$ is the target of all identified regulation affecting the levansucrase gene in Bacillus subtilis. J Bacteriol 166, 993-998.

Chambert, R. \& Gonzy-Tréboul, G. (1976). Levansucrase of Bacillus subtilis: kinetic and thermodynamic aspects of transfructosylation processes. Eur J Biochem 62, 55-64.

Chambert, R. \& Petit-Glatron, M.F. (1984). Hyperproduction of exocellular levansucrase by Bacillus 
subtilis: examination of the phenotype of a sacUh strain. $J$ Gen Microbiol 130, 3143-3152.

Chambert, R. \& Petit-Glatron, M.F. (1988). Secretion mechanism of Bacillus subtilis levansucrase: characterization of the second step. J Gen Microbiol 134, 1205-1214.

Chambert, R. \& Petit-Glatron, M.F. (1993). Immobilisation of levansucrase on calcium phosphate gel strongly increases its polymerase activity. Carbohydr Res 244, 129-136.

Chambert, R., Tréboul, G. \& Dedonder, R. (1974). Kinetic studies of levansucrase of Bacillus subtilis. Eur $J$ Biochem 41, 285-300.

Chambert, R., Rain-Guion, M.C. \& Petit-Glatron, M.F. (1992). Readthrough of the Bacillus subtilis levansucrase stop codon produces an extended enzyme displaying a higher polymerase activity. Biochim Biophys Acta 1132, 145-153.

Crutz, A.M., Steinmetz, M., Aymerich, S., Richter, R. \& Le Coq, D. (1990). Induction of levansucrase in Bacillus subtilis: an antitermination mechanism negatively controlled by the phosphotransferase system. J Bacteriol 172, 1043-1050.

Débarbouillé, M., Martin-Verstraete, I., Arnaud, M., Klier, A. \& Rapoport, G. (1991). Positive and negative regulation controlling expression of the sac genes in Bacillus subtilis. Res Microbiol 142, 757-64.

Declerck, N., Minh, N.L., Yang, Y., Bloch, V., Kochoyan, M. \& Aymerich S. (2002). RNA recognition by transcriptional antiterminators of the $\mathrm{BglG} / \mathrm{SacY}$ family: mapping of SacY RNA binding site. $J$ Mol Biol 319,1035-1048.

Dedonder, R. (1966). Levansucrase from Bacillus subtilis. Meth Enzymol 8, 500-506.

Goldberger, R. (1974). Autogenous regulation of gene expression. Science 183, 810-816.

Henkin, T.M. \& Yanofsky, C. (2002). Regulation by transcription attenuation in bacteria: how RNA provides instructions for transcription termination/antitermination decisions. Bioessays 24, 700-707.

Hesselberth, J.R. \& Ellington, A.D. (2002). A (ribo)switch in the paradigms of genetic regulation. Nature structural biology 9, 891-893.

Idelson, M. \& Amster-Choder, O. (1998). SacY, a transcriptional antiterminator from Bacillus subtilis, is regulated by phosphorylation in vivo. J Bacteriol 180, 660666.

Kunst, F., Ogasawara, N., Moszer, I. \& 148 other authors (1997). The complete genome sequence of the gram-positive bacterium Bacillus subtilis. Nature 390, 249256.

Le Hir, H., Nott, A. \& Moore, M.J. (2003). How introns influence and enhance eukaryotic gene expression. Trends Biochem Sci 28, 215-220.

Leloup, L., Haddaoui, E., Chambert, R. \& PetitGlatron, M.F. (1997). Characterization of the rate-limiting step of the secretion of Bacillus subtilis alpha-amylase overproduced during the exponential phase of growth. Microbiology 143, 3295-3303.
Leloup, L., Le Saux, J., Petit-Glatron, M.F. \& Chambert, R. (1999). Kinetics of the secretion of Bacillus subtilis levanase overproduced during the exponential phase of growth. Microbiology 145, 613-619.

Lepesant, J.A., Kunst, F., Lepesant-Kejzlarova, J. \& Dedonder, R. (1972). Chromosomal location of mutations affecting sucrose metabolism in Bacillus subtilis Marburg. Mol Gen Genet 118, 135-160.

Lepesant, J.A., Kunst, F., Pascal, M., LepesantKejzlarova, J. , Steinmetz, M. \& Dedonder, R. (1976). Specific and pleiotropic regulatory mechanism in the sucrose system of Bacillus subtilis. In Microbiology 1976, pp. 58-69. Edited by D. Schlessinger. Washington, DC: American Society for Microbiology.

Manival, X., Yang, Y., Strub, M.P., Kochoyan, M., Steinmetz, M. \& Aymerich, S. (1997). From genetic to structural characterization of a new class of RNA-binding domain within the $\mathrm{SacY} / \mathrm{BglG}$ family of antiterminator proteins. EMBO J 16, 5019-5029.

Nudler, E. \& Mironov, A.S. (2004). The riboswitch control of bacterial metabolism. Trends Biochem Sci 29, 11-17.

Pereira, Y., Chambert, R., Leloup, L., Daguer, J. P. \& Petit-Glatron, M.F. (2001a). Transcripts of the genes $s a c B, a m y E, s a c C$ and $c s n$ expressed in Bacillus subtilis under the control of the $5^{\prime}$ untranslated $s a c R$ region display different stabilities that can be modulated. Microbiology 147, 1331-1341.

Pereira, Y., Petit-Glatron, M.F. \& Chambert, R. (2001b). yveB, Encoding endolevanase LevB, is part of the sacB-yveB-yveA levansucrase tricistronic operon in Bacillus subtilis. Microbiology 147, 3413-3419.

Petit-Glatron, M.F. \& Chambert, R. (1981). Levansucrase of Bacillus subtilis: Conclusive evidence that its production and export are unrelated to fatty-acid synthesis but modulated by membrane-modifying agents. Eur J Biochem 119, 603-611.

Petit-Glatron, M.F. \& Chambert, R. (1992). Peptide carrier potentiality of Bacillus subtilis levansucrase. J Gen Microbiol 138, 1089-1095.

Rapoport, G. \& Dedonder, R. (1963). La lévane saccharase de Bacillus subtilis. II. Hydrolyse et transfert à partir des lévanes. Bull Soc Chim Biol 45, 493-513.

Rolland, F., Moore, B. \& Sheen., J. (2002). Sugar sensing and signaling in plants. Plant Cell 14, 185-205.

Rygus, T., Scheler, A., Allmansberger, R. \& Hillen, W. (1991). Molecular cloning, structure, promoters and regulatory elements for transcription of the Bacillus megaterium encoded regulon for xylose utilization. Arch Microbiol 155, 535-542.

Sambrook, J., Fritsch, E.F. \& Maniatis, T. (1989). Molecular Cloning: a Laboratory Manual, 2nd edn. Cold Spring Harbor, NY: Cold Spring Harbor Laboratory.

Serfling, E. (1989). Autoregulation--a common property of eukaryotic transcription factors? Trends Genet 5, 131-133.

Smeekens, S. (2000). Sugar-induced signal transcduction in plants. Annu Rev Physiol Plant Mol Biol 51,49-81.

Steinmetz, M., Le Coq, D., Aymerich, S., GonzyTréboul, G. \& Gay, P.(1985). The DNA sequence of the 
gene for the secreted Bacillus subtilis enzyme levansucrase and its genetic control sites. Mol Gen Genet 200, 220-228.

Tortosa, P. \& Le Coq, D. (1995). A ribonucleic antiterminator sequence (RAT) and a distant palindrome are both involved in sucrose induction of the Bacillus subtilis sacXY regulatory operon. Microbiology 141, 29212927.

Tortosa, P., Aymerich, S., Lindner, C., Saier, M.H. Jr, Reizer, J. \& Le Coq, D. (1997). Multiple phosphorylation of SacY, a Bacillus subtilis transcriptional antiterminator negatively controlled by the phosphotransferase system. $J$ Biol Chem 272, 17230-17237.

Yang, Y., Declerck, N., Manival, X., Aymerich, S. \& Kochoyan, M. (2002). Solution structure of the LicT-RNA antitermination complex: CAT clamping RAT. EMBO J 21, 1987-1997. 


\begin{tabular}{|c|c|c|}
\hline Strain/plasmid & Relevant Genotype and Phenotype & Source or reference \\
\hline \multicolumn{3}{|l|}{ Strains } \\
\hline QB112 & $\operatorname{deg} U 32(\mathrm{Hy}) \operatorname{sacA321}$ & Lepesant et al., 1974 \\
\hline GM96100 & $\mathrm{QB} 112 \Delta s a c R-s a c B ; \mathrm{Sp}^{\mathrm{R}}$ & Leloup et al., 1997 \\
\hline GM2101 & $\mathrm{QB} 112 \Delta s a c R-s a c B:: s a c R-s a c B ; \mathrm{Km}^{\mathrm{R}}$ & This work \\
\hline GM2102 & QB112 $\Delta$ sacR-sacB::sacR-levB; $\mathrm{Km}^{\mathrm{R}}$ & This work \\
\hline GM2201 & QB112 $\Delta s a c R-s a c B$ sacR'-sacB::pWH1520; $\mathrm{Km}^{\mathrm{R}} \mathrm{Tet}^{\mathrm{R}}$ & This work \\
\hline GM2202 & QB112 $\Delta s a c R-s a c B$ sacR'-sacB::pWHlevB; $\mathrm{Km}^{\mathrm{R}}$ Tet $^{\mathrm{R}}$ & This work \\
\hline GM2203 & QB112 $\Delta$ sacR-sacB sacR'-sacB::pWHyveA; $\mathrm{Km}^{\mathrm{R}} \mathrm{Tet}^{\mathrm{R}}$ & This work \\
\hline GM2204 & QB112 $\Delta$ sacR-sacB sacR'-sacB::pWHlevBmut; $\mathrm{Km}^{\mathrm{R}}$ Tet $^{\mathrm{R}}$ & This work \\
\hline \multicolumn{3}{|l|}{ Plasmids } \\
\hline pLS50 & $\mathrm{Ap}^{\mathrm{R}}, \mathrm{Cm}^{\mathrm{R}}$ & Steinmetz et al., 1985 \\
\hline pGMK50 & pLS50 derivative; $\mathrm{Km}^{\mathrm{R}}, \mathrm{Ap}^{\mathrm{R}}, \mathrm{Cm}^{\mathrm{R}}$ & Chambert et al., 1992 \\
\hline pGMK $\Delta 50$ & pGMK50 $\Delta E c o R V ; \mathrm{Km}^{\mathrm{R}}, \mathrm{Ap}^{\mathrm{R}}, \mathrm{Cm}^{\mathrm{R}}$ & This work \\
\hline pGMK80 & $\mathrm{pGMK} \Delta 50 \mathrm{H} 1 ; \mathrm{Km}^{\mathrm{R}}, \mathrm{Ap}^{\mathrm{R}}, \mathrm{Cm}^{\mathrm{R}}$ & This work \\
\hline pGMK81 & pGMK $\Delta 50 \mathrm{H} 1 s a c R-s a c B ; \mathrm{Km}^{\mathrm{R}}, \mathrm{Ap}^{\mathrm{R}}, \mathrm{Cm}^{\mathrm{R}}$ & This work \\
\hline pGMK82 & $\mathrm{pGMK} \Delta 50 \mathrm{H} 1$ sacR-levB; $\mathrm{Km}^{\mathrm{R}}, \mathrm{Ap}^{\mathrm{R}}, \mathrm{Cm}^{\mathrm{R}}$ & This work \\
\hline pWH1520 & $\operatorname{Tet}^{\mathrm{R}} \mathrm{Ap}^{\mathrm{R}}$ & Scheler et al., 1991 \\
\hline pWHlevB & pWH1520 levB; Tet $^{\mathrm{R}} \mathrm{Ap}^{\mathrm{R}}$ & This work \\
\hline pWHyveA & pWH1520 yveA; Tet $^{\mathrm{R}} \mathrm{Ap}^{\mathrm{R}}$ & This work \\
\hline pWHlevBmut & pWH1520 levBmut; Tet $^{\mathrm{R}} \mathrm{Ap}^{\mathrm{R}}$ & This work \\
\hline pGMC9 & $\mathrm{pCR}(+) s a c R ; \mathrm{Ap}^{\mathrm{R}}$ & Leloup et.al., 1997 \\
\hline pGMC20 & $\mathrm{pCR}(+) \mathrm{H} 1 ; \mathrm{Ap}^{\mathrm{R}}$ & This work \\
\hline pGMC21 & $\mathrm{pCR}(+) \operatorname{lev} B ; \mathrm{Ap}^{\mathrm{R}}$ & This work \\
\hline pGMC22 & $\mathrm{pCR}(+)$ yve $A ; \mathrm{Ap}^{\mathrm{R}}$ & This work \\
\hline pGMC23 & $\mathrm{pCR}(+)$ levBmut; $\mathrm{Ap}^{\mathrm{R}}$ & This work \\
\hline pGMC24 & pGMC9 $s a c B$ Ap ${ }^{\mathrm{R}}$ & This work \\
\hline
\end{tabular}


Table 2. Oligonucleotides used in this study

Oligonucleotides $\left(5^{\prime}-3^{\prime}\right)$

Restriction site at the 5' end

LS-fw: GGAGACGTCAACGATGAACATCA

Aat II

LS-rev: CCGCTCGAGGGAATACGGTTAGCCATTTGCCTGC

XhoI

yveA-fw: GGACTAGTGCGGTATTCTCTGTTACATATTGG

SpeI

yveA-rev: GGGGTACCGGCATGAGGAACACCTCC

KpnI

levB-fw: GGACTAGTGCAAAAGAAAATGCCGCCGATATCC

SpeI

levB-rev1: GGGGTACCCAATATGTAACAGAGAATACCGC

Kpn I

levB-rev2: TAGCCATTTCCCCGCCTTTATATAGTTCATAT

levBmut ${ }^{\mathrm{a}}$ : AACTATATAAAGGCGGGGAAATGGCTAACC

H1-fw: TCCCCCGGGCCATCCTCCGCTGCTGTGGCTG

$A v a \mathrm{I}$

H1-rev: GATGGGTTAAAAAGGATCCCTAACTGAAGGA

BamHI

5S RNA probe: ACTACCATCGGCGCTGAAGA

levB-T $7^{\text {b }}$ : tgtaatacgactcactataggTGAATCCCATATGAACTA

levB-332rev: CCGGTAGTCCGGCTTCTG

\footnotetext{
${ }^{a}$ Modified nucleotides are indicated in bold

${ }^{\mathrm{b}}$ Lower-case letters indicate the T7 polymerase promoter site.
} 
(a)

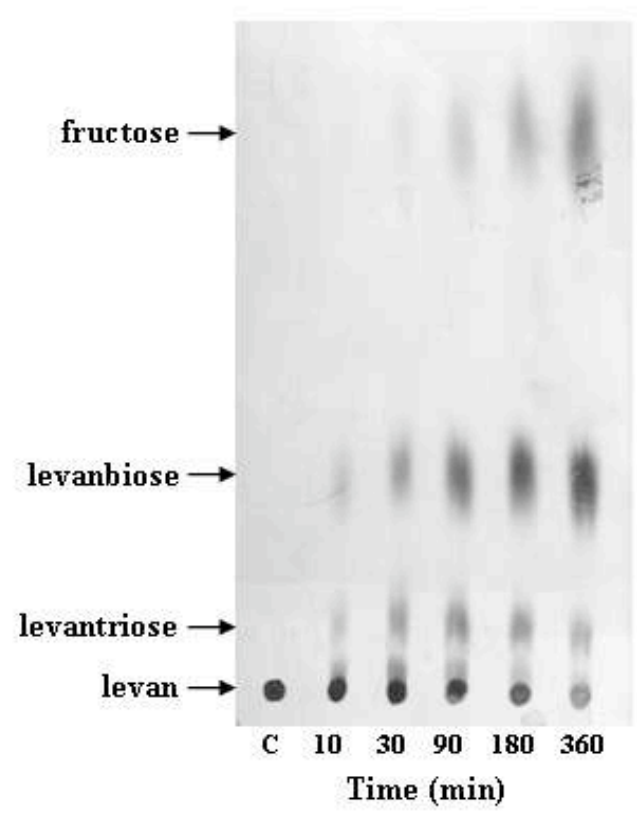

(b)

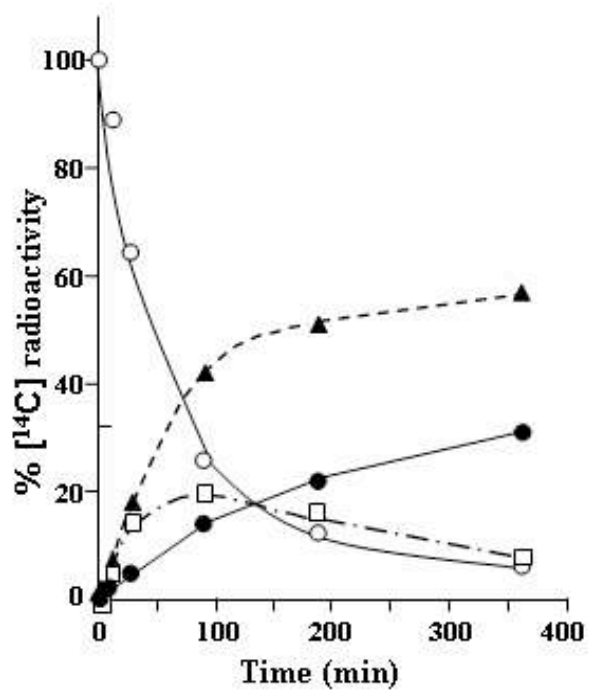

Figure 1. Levan degradation by LevB.

The reaction mixtures $(60 \mu \mathrm{l})$ contained $20 \mathrm{mg} \mathrm{ml}^{-1}\left[{ }^{14} \mathrm{C}\right]$-levan in $0.1 \mathrm{M}$ potassium phosphate, $\mathrm{pH} 6$. Reactions were initiated by the addition of a suspension of membranes isolated from strain GM2102 grown in the presence of $50 \mathrm{mM}$ sucrose. At the indicated intervals, samples $(10 \mu \mathrm{l})$ were removed. ${ }^{14} \mathrm{C}$ labelled sugars were identified by paper chromatography (a) and quantitatively estimated (b). ( o levan), ( $\square$ levantriose), ( $\boldsymbol{\Delta}$ levanbiose), (• fructose).

Control (C) was achieved by incubation of labelled levan for $360 \mathrm{~min}$ in the presence of a membrane suspension isolated from strain GM2102 grown in the absence of sucrose. 
Figure 2

(a)

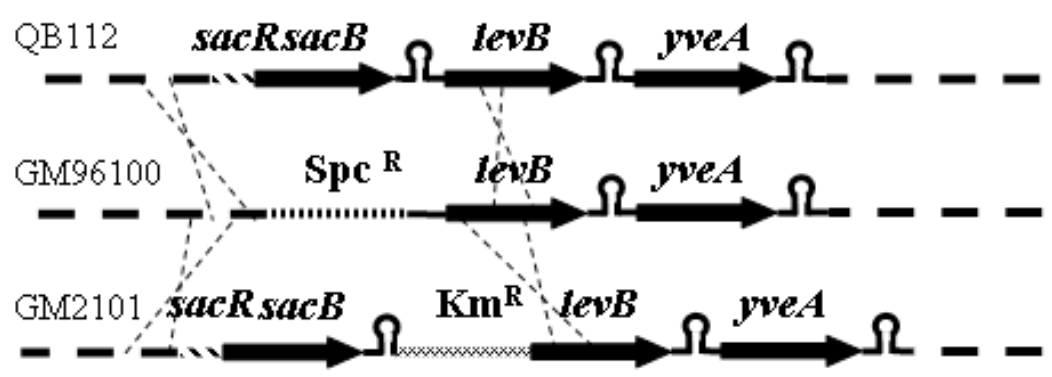

(b)

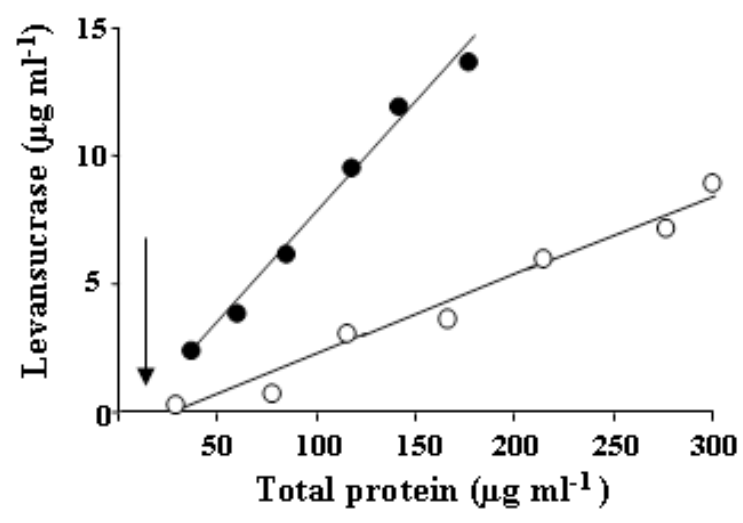

Figure 2.

(a) Schematic representation of the double crossing-over insertion of $\operatorname{sacR}$-sacB fusion into the $B$. subtilis chromosome. (b) Levansucrase production by B. subtilis QB112(•) and its derivative strain GM2101 (०).

The arrow indicates the addition of $50 \mathrm{mM}$ sucrose to exponentially growing cells, at an $\mathrm{OD}_{600}$ of 0.2 . Levansucrase was assayed by measuring the initial rate of the fructosyl exchange reaction (Chambert \& Petit-Glatron, 1984). 
Figure 3

(a)

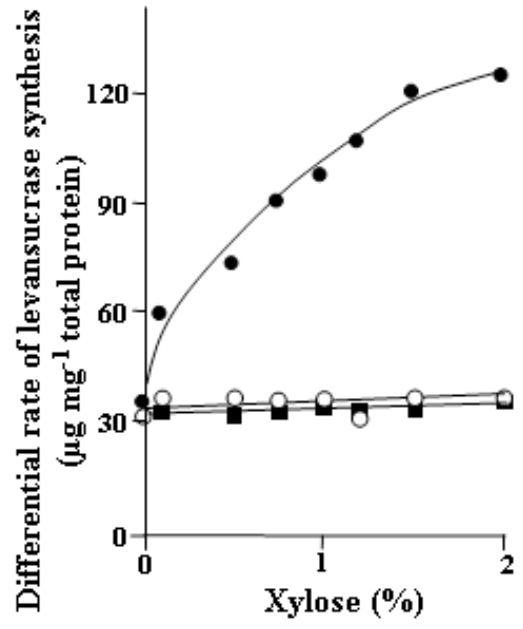

(b)

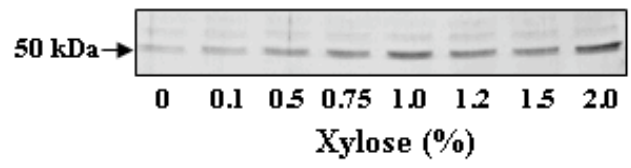

Figure 3. Production of levansucrase in strains GM2201, GM2202 and GM2203.

(a) Cell suspensions of each strain grown in minimal medium were divided into equal portions at $\mathrm{OD}_{600}=0.2$ in flasks containing sucrose $(50 \mathrm{mM})$ and various concentrations of xylose. During exponential growth, samples of the suspensions were withdrawn at intervals.

Levansucrase production by strains GM2201 (०), GM2202 (•) and GM2203 (•) was estimated from the differential rate of levansucrase synthesis at each xylose concentration (Chambert \& Petit-Glatron, 1984).

(b) SDS-PAGE analysis of the supernatant $\left(40 \mu 1\right.$, at $\left.\mathrm{OD}_{600}=1\right)$ of strain GM2202 grown in minimal medium in the presence of $50 \mathrm{mM}$ sucrose and different concentrations of xylose. The arrow corresponds to levansucrase $(50 \mathrm{kDa})$. 
(a)

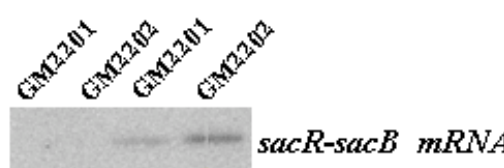

5S RNA

$+++\quad+\quad$ xylose

$-\quad++$ sucrose

(b)

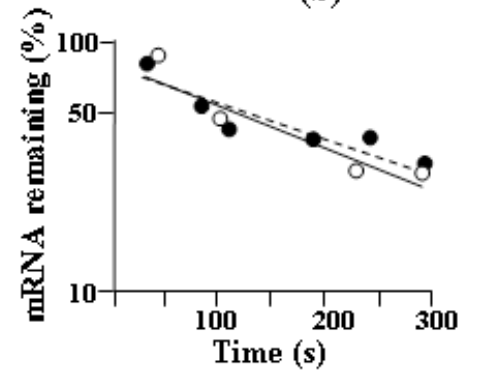

(c)

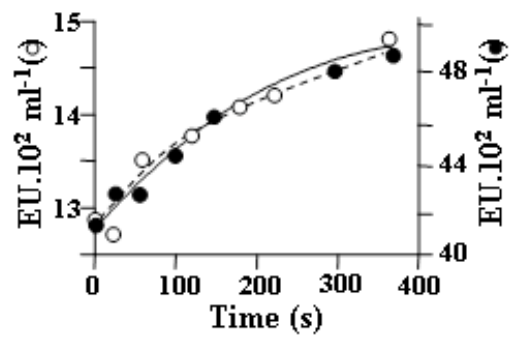

Figure 4. Steady state and stability analyses of $s a c B$ transcripts in strains GM2201 and 2202. (a) Strains GM2201 and GM2202 were grown in minimal medium in the presence (+) or absence (-) of $50 \mathrm{mM}$ sucrose and in the presence of $1 \%(\mathrm{w} / \mathrm{v})$ xylose added to the cultures at $\mathrm{OD}_{600}=0.2$. Samples of the cultures were withdrawn at $\mathrm{OD}_{600}=1.5$, immediately frozen in liquid nitrogen and then treated as described in Methods. RNA preparations $(10 \mu \mathrm{g})$ were analyzed by Northern blotting. Hybridization was done with a $\left[{ }^{33} \mathrm{P}\right]$ labelled $s a c R$ probe (Pereira et al., 2001b).

(b) Stability of $s a c B$ mRNA in strains GM2201 and GM2202. Samples were withdrawn at intervals after the addition of rifampicin from cultures grown in the presence of $50 \mathrm{mM}$ sucrose and $1 \%$ xylose, treated and analyzed as described in Methods. Decay curves of $s a c B$ mRNA stability in strains GM2201 (०) and GM2202 (•) were estimated from the quantification of the Northern blot experiment. The $s a c B$ mRNA half-lives were determined using Sigma plot software. (c) Functional $s a c B$ mRNA decay was estimated by levansucrase production subsequent to rifampicin addition in strains GM2201 (०) and GM2202 (•) grown as indicated in (b). 
(a)

(b)

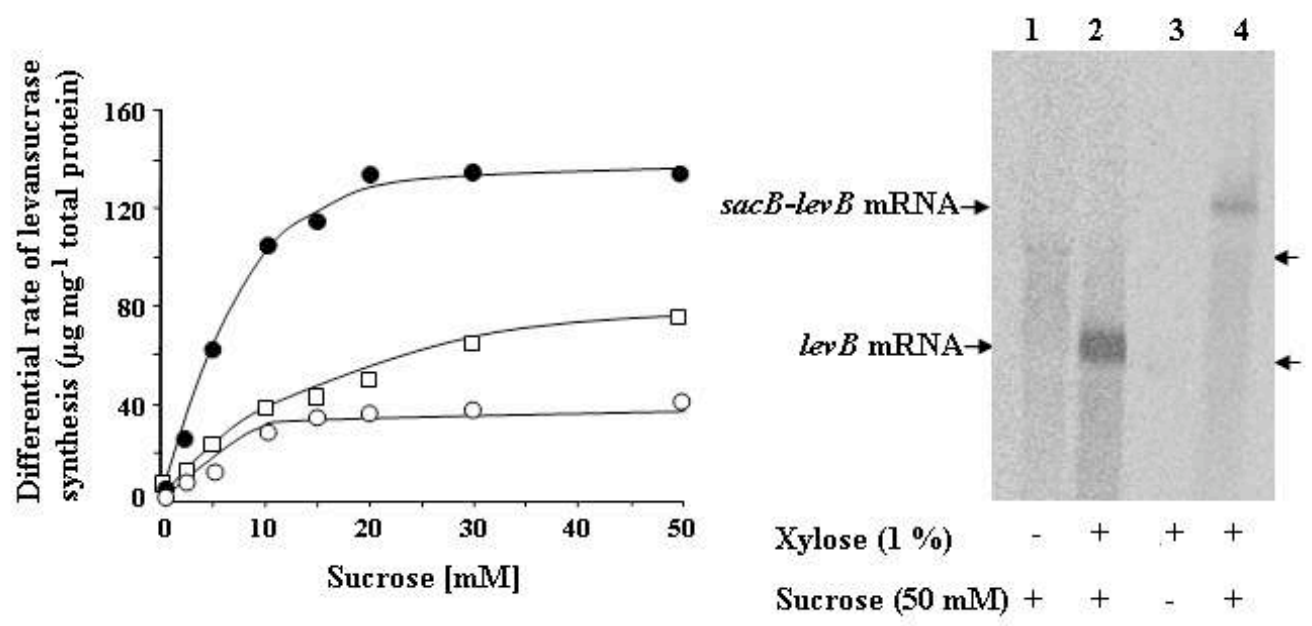

Figure 5.

(a) Induction pattern of SacB production in strains GM2201 (०), GM2202(•) and QB112 (ㅁ).

Cells were grown in minimal medium in the presence of sucrose at various concentrations and $1 \%$ xylose. The differential rate of levansucrase synthesis was evaluated at each sucrose concentration as described (Chambert \& Petit-Glatron, 1984).

(b) Northern blotting analysis of levB and $s a c B-l e v B$ transcripts in strains GM2202 and QB112.

Cells of strain GM2202 were grown in minimal medium supplemented with $50 \mathrm{mM}$ sucrose in the absence (lane 1) or presence (lane 2) of $1 \%$ xylose as indicated. Cells of strain QB112 were grown in minimal medium supplemented with $1 \%$ xylose in the absence (lane 3) or presence (lane 4) of $50 \mathrm{mM}$ sucrose. Samples $(10 \mu \mathrm{g}$ ) of each RNA preparation were analyzed by Northern blotting.

Hybridization was done with the $\left[{ }^{33} \mathrm{P}\right]$ labelled levB probe, as described in Methods. Migration of the $23 \mathrm{~S}(2928 \mathrm{nt})$ and $16 \mathrm{~S}$ (1553 nt) is indicated by arrowheads on the right. 
Figure 6

(a)

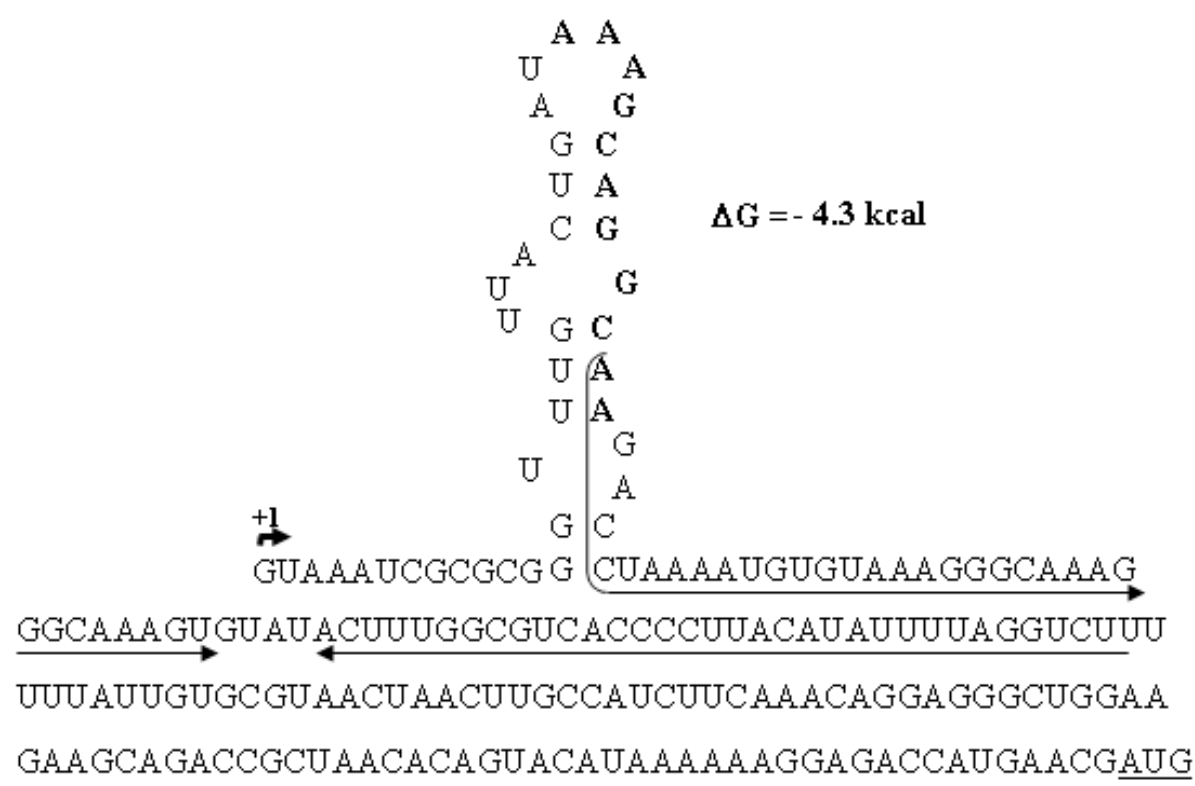

(b)

$5 ’$ -

(c)

5 - $\underline{\text { AUG }}$ AAC UAU AUA AAG GCG GGG AAA UGG CUA ACC GUA .....

\section{Figure 6.}

(a) $\underline{s a c B}$ transcript. The 5 ' untranslated region of the transcript is shown (the start transcription is indicated) with the potential secondary structure of the Ribonucleic AntiTerminator (RAT) and the Rho independent terminator alternative structure, marked by an arrow. The start translation codon of $s a c B$ is underlined.

(b) Sequence of the 5' coding region of $\operatorname{lev} B$ transcript. The motif of eleven nucleotides homologous to that present in the RAT is indicated in bold.

(c) Sequence of the 5 ' coding region of lev $B$ transcript in pWHlevmut. In $b$ ) and c), the start translation codon of $\operatorname{lev} B$ is underlined. 
Figure 7

(a)

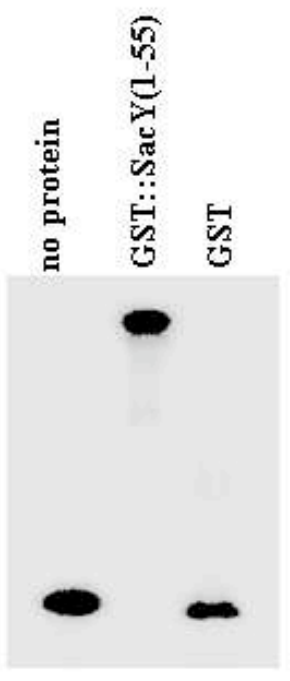

GST: :SacY (1-55)

$\begin{array}{lllllllllll}0 & 0.1 & 05 & 1 & 3 & 5 & 7 & 10 & \mu M\end{array}$

(c)
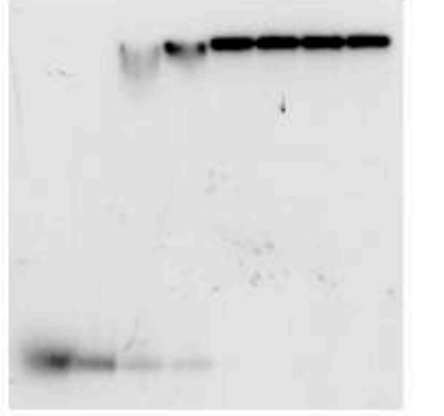

(b)

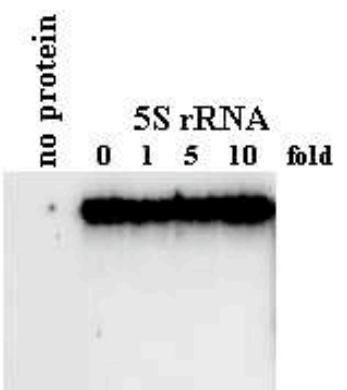

(d)

GST: :SacY (1-55)

$\begin{array}{lllllllllll}0 & 05 & 1 & 3 & 5 & 7 & 10 & \mu M\end{array}$

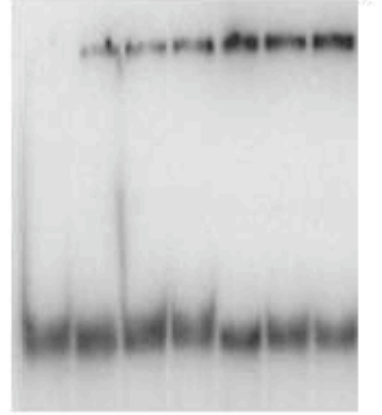

Figure 7. Gel mobility shift assay.

For all binding reactions, the reaction mixture contained $0.1 \mathrm{pmol}$ of labelled transcript (prepared as described in Methods using as DNA template pWHlevB in a, b,and c or pWHlevBmut in d), $1 \mu \mathrm{g}$ of yeast RNA, $10 \mu \mathrm{g}$ of BSA and $1 \mathrm{U}$ of RNase inhibitor (rRNasin, Promega) in $9 \mu$ l of $1 \mathrm{x}$ binding buffer $(50 \mathrm{mM}$ Tris-HCl, $\mathrm{pH} 7.5 ; 250 \mathrm{mM} \mathrm{NH4Cl;1} \mathrm{mM} \mathrm{EDTA;} 5 \%$ (w/v) glycerol; $0.1 \%(\mathrm{v} / \mathrm{v})$ Triton-X100). Samples were prepared by addition of (a) $1 \mu \mathrm{M}$ of purified GST::SacY(1-55) or GST, (b) $1 \mu 1$ of $5 \mathrm{~S}$ rRNA of various concentrations prior to the addition of $1 \mu \mathrm{M} \mathrm{SacY}$ (the molar excess of $5 \mathrm{~S}$ rRNA is indicated at the top of the lane), (c and d) $1 \mu 1$ of purified GST::SacY(1-55) of various concentrations. The samples were incubated at $25^{\circ} \mathrm{C}$ for $30 \mathrm{~min}$ and analyzed on a $5 \%$ native polyacrylamide gel run in $1 \mathrm{x}$ TBE at $4{ }^{\circ} \mathrm{C}$. 
Figure 8

(a)

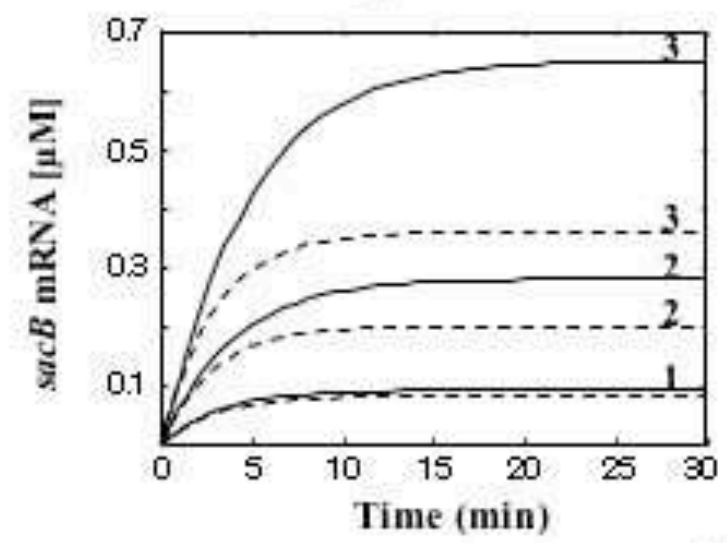

(b)

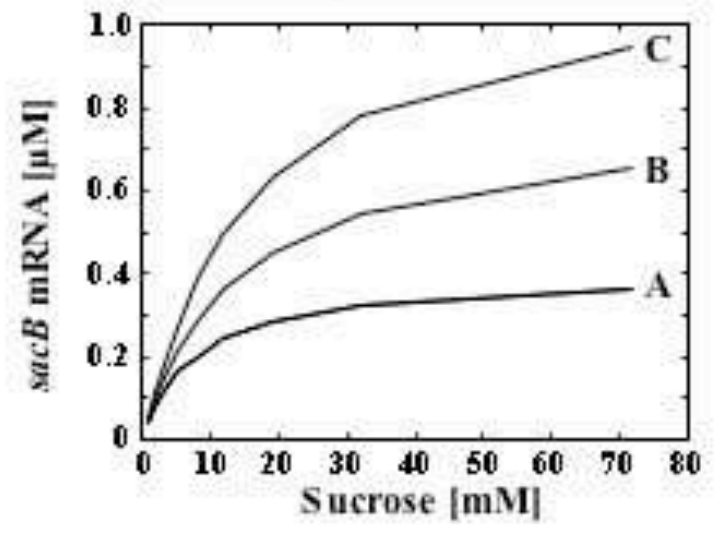

(c)

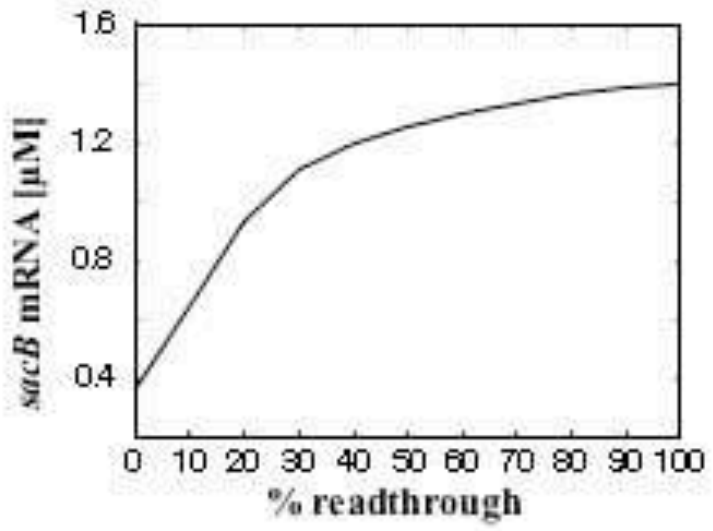

Figure 8. Simulation exploring effects of nositive feedback loon on the dvnamics of sack mRNA nroduction.

(a) [sacB mRNA] versus time subsequent to induction by sucrose. Curves in dotted line are obtained using equation [2a] (absence of loop) and in continuous line using equation [3]. Inducer concentrations corresponding to $0.1 \mathrm{~K}_{1}, \mathrm{~K}_{1}$ and $9 \mathrm{~K}_{1}$, are indicated by 1, 2 and 3 , respectively. The numerical simulations were obtained with $\mathrm{K}_{\mathrm{D}}=0.2 \mu \mathrm{M}$ and $\mathrm{k}_{\mathrm{d}}=0.35 \mathrm{~min}^{-1}$. (b) Steady state values of $s a c B$ mRNA versus inducer concentrations. $A$ : in the absence of a positive loop; $B$ and $C$ : in the presence of a positive loop with $K_{\mathrm{o}}=0.2 \mu \mathrm{M}$ and $\mathrm{K}_{\mathrm{v}}=0.1$ $\mu \mathrm{M}$, respectively.

(c) Steady state values of $s a c B$ mRNA with respect to an increase of readthrough of the internal terminator structure between $s a c B$ and $l e v B$ genes. The numerical simulation was obtained with $\mathrm{K}_{\mathrm{r}}=0.2 \mu \mathrm{M}, \mathrm{I}=9 \mathrm{~K}_{\mathrm{I}}$. 
(b)

(a)

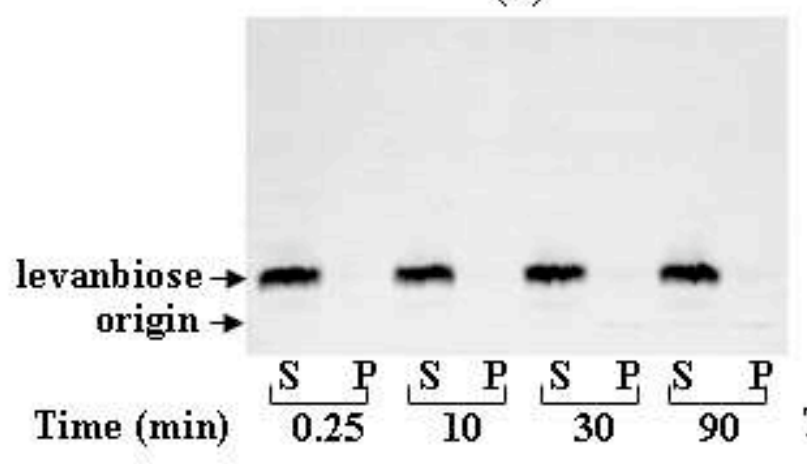

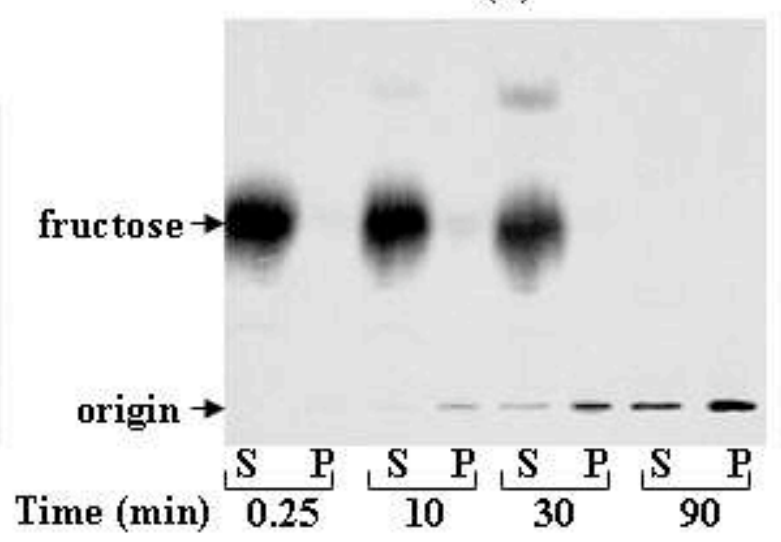

(c)

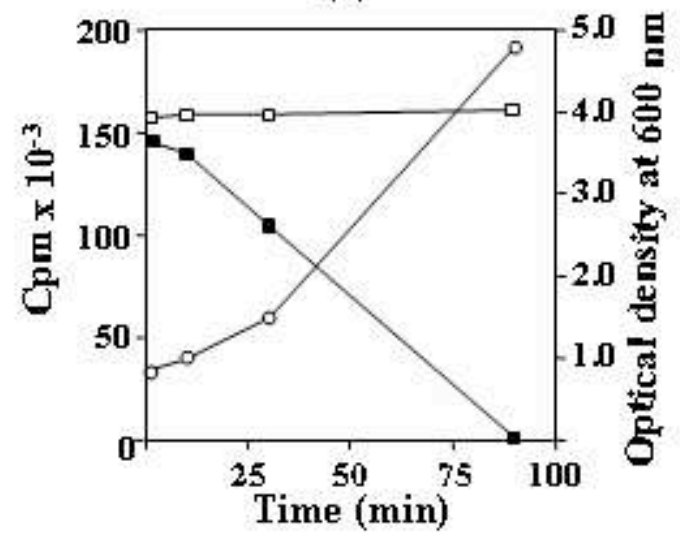

Figure 9. Uptake of fructose and levanbiose by B. subtilis QB112 strain.

Cells were grown in YT medium (Sambrook et al., 1989). $\left[{ }^{14} \mathrm{C}\right]$ levanbiose $(0.4 \mathrm{mM})$ or $\left[{ }^{14} \mathrm{C}\right]$ fructose $(0.4 \mathrm{mM})$ were added to 2 $\mathrm{ml}$ of cell suspension at $\mathrm{OD}_{600}=0.4$. Aliquots $(0.5 \mathrm{ml})$ were removed at intervals as indicated and centrifuged. Cell pellets were resuspended in $0.5 \mathrm{ml}$ of $0.05 \mathrm{M}$ sodium phosphate $\mathrm{pH} 7.0$ in the presence of lysozyme $\left(100 \mu \mathrm{g} \mathrm{ml}^{-1}\right)$. The same volume of cell supernatant and lyzed cell suspension were submitted to paper chromatography analysis with n-butanol/acetic acid/water (4/1/1 volume by volume) as developing solvent.

Distribution of radioactivity between cells and cell supernatants: cells growing in the presence of $\left[{ }^{14} \mathrm{C}\right]$ levanbiose (a) or $\left[{ }^{14} \mathrm{C}\right]$ fructose (b). S and P indicate supernatant and pellet, respectively Quantitative evaluation of labelled sugar remaining in culture supernatant $(\mathrm{c})$ : $[14 \mathrm{C}]$ levanbiose $(\square)$; $\left[{ }^{14} \mathrm{C}\right]$ fructose (a); culture growth (०). 